\title{
TITLE:
}

\section{SYSTEMATIC STUDIES ON THALASSINIDEA -I. LAOMEDIA ASTACINA DE HAAN-}

$\operatorname{AUTHOR}(S)$ :

Sakai, Katsushi

\section{CITATION:}

Sakai, Katsushi. SYSTEMATIC STUDIES ON THALASSINIDEA -I. LAOMEDIA ASTACINA DE HAAN-. PUBLICATIONS OF THE SETO MARINE BIOLOGICAL LABORATORY 1962, 10(1): 27 34

ISSUE DATE:

1962-07-30

URL:

http://hdl.handle.net/2433/175300

RIGHT: 


\title{
SYSTEMATIC STUDIES ON THALASSINIDEA
}

\section{LAOMEDIA ASTACINA DE HAAN ${ }^{1)}$}

\author{
KATSUSHI SAKAI \\ Zoological Laboratory, Faculty of Agriculture, \\ Kyushu University, Fukuoka
}

With Plates V-VII

There exist a few incomplete descriptions about the structure of Laomedia astacina DE HAAN, but their details and further investigations have not yet been done.

DE HAAN (1841, '49) paid a noticeable attention to the structure of his material Laomedia, in addition to the gill formula and its number, and the estimation thirteen in number. Following him, OrTMANN (1892) reported fourteen gills on his material from Tokyo Bay, though it was a little broken unfortunately. The problems on the gill formula of gnathobranchs and its number have been uncertain, while they had decided on the other two genera, Jaxea and Naushonia (GURNEY, 1942). I've speculated about the epipodites summed up by GURNEY (1942), but in this report I've accounted for the structure of gills and other parts, using the materials deposited in our Laboratory.

Here I wish to express my thanks to Professor Sadayoshi Mryake for suggesting this investigation as well as for constant guidance in the course of the work.

\section{Laomedia astacina DE HAAN}

Laomedia astacina DE HAAN, 1849, p. 165, ser. 35, fig. 8-Japan.

" ORTMANN, 1892, p. 51-Tokyo Bay.

" Borradaile, 1903, p. 540.

" Balss, 1914, p. 88-Nagasaki, Satuma.

" Kamit A, 1957, p. 105-106, fig. 47-Schuan, near Zinsen, Korea.

Materials examined.-

$10^{7}$, Cat. No. 4365, c.1., 1.9 mm, Komi, Iriomote-Isl., Ryukyu, Feb. 19, 1937, coll. by $\mathrm{H}$. Ohshima \& S. Miyake.

1) Contributions from the Zoological Laboratory, Faculty of Agriculture, Kyushu University, No. 304.

Publ. Seto Mar. Biol. Lab., X (1), 1962. (Article 3) 
1 우 , Cat. No. 4096, c.l., 13.5 mm, Amakusa, Kumamoto Pref., Feb. 8, 1939, coll. by $K$. BABA.

3 o , Cat. No. 4831-'33, c.1., 1.6, 1.6, 1.7 mm, Amakusa, May 29, 1957.

2 , Cat. No. 7298, c.1., 9.0, $20.0 \mathrm{~mm}$, at the estuary of River Tatara, Fukuoka Pref., June 17, 1959, coll. by Y. Ono \& A. TAKI.

1 , Cat. No. 7366, c.l., $20.0 \mathrm{~mm}$, Tatara, Sept. 7, 1959, coll. by A. TAKI.

1 ㅇ, Cat. No. s-53, c.1., 24.0 mm, Wajiro, Hakata Bay, Fukuoka, Apr. 27, 1961, coll. by $\mathrm{Y}$. ONo.

$1 \%$, in berry, Cat. No. s-54, c.l., $21.6 \mathrm{~mm}$, Tatara, May 13, 1961, coll. by K. SaKaI.

The descriptions and measurments given in this report are mainly based upon the material, Cat. No. s-54, collected from the River Tatara, Fukuoka, on 13th May, 1961. I've used another specimen (Cat. No. s-53) from the near locality to see the gill structure more carefully. And the other specimens, one male and eight females without eggs, are also inspected.

Description.-A female (Cat. No. s-54) $59.0 \mathrm{~mm}$ in total length. The carapace is $21.6 \mathrm{~mm}$ in length, $0.7 \mathrm{~mm}$ in breadth, and $11.0 \mathrm{~mm}$ in depth; the cervical groove is distinct, and divides the back of carapace into two equal parts, the anterior and the posterior parts. In the anterior part there are rostrum and gastric region. In the posterior part it consists of three parts, mascular, cardiac and posterior regions. The posterior margin on the back of carapace is in contact with a marginal zone of branchial region, and following to this connection it curves backwards and so forms a rounded concavity; linea thalassinica fairly distinct; under this groove there are antennal, maxillary, branchial regions and marginal zone distinguishable. In this specimen villi are well developed on the maxillary and antennal regions, but in the other specimens more dishevelled; the length of first, second, third, fourth, fifth and sixth abdominal segments are 1.0, $5.0,5.0,4.7,4.7$ and $5.5 \mathrm{~mm}$, and on each of them a border between pleura and tergum is fairly well distinct except the last segment of abdomen; in the pleura the first, second, third, fourth, fifth and sixth are $0.7,3.0,3.2,3.5,3.5$ and $2.5 \mathrm{~mm}$ in depth. The first is small but distinct, the second of a good size, getting its posterior angle curve backwards, and the sixth makes its posterior half concave inside. Hairs, about $3.0 \mathrm{~mm}$ in length, form a border to the distal margin of pleura; the telson $7.5 \mathrm{~mm}$ in length and its posterior angle rounded.

The eye below the rostrum. In the antennule the basal segment is $5.0 \mathrm{~mm}$, and the flagellum $10.0 \mathrm{~mm}$, about 42 joints. The first segment $2.0 \mathrm{~mm}$ behind the eye, but it does not reach the rostrum. The second $1.3 \mathrm{~mm}$, coverd with long hairs on both sides, a little longer than the third $(1.0 \mathrm{~mm})$. In the antenna the coxopodite large and broad, the basal segment $5.9 \mathrm{~mm}$, and the flagellum $44.5 \mathrm{~mm}$. At the middle of coxopodite the opening of green gland is clearly seen. The basal segment is chiefly divided into three parts, the first segment of antenna, the 
second and the third. The first segment of antenna is very complicated and difficult to see the correct structure, but here I've observed the following fact. In the first segment of antenna the basiopodite and ischiopodite are fused together. The basiopodite corresponds to the dorsal plate which is divided into two sections, the inner one with a antennal scale $(1.0 \mathrm{~mm})$, and the outer with a antennal thorn. On the other hand, in the ischiopodite occupied by the lateral and ventral surface, the lateral surface is furthermore divided into two sections and served as a basal part of the ventral plate, which is simple.

The mandible ends in six teeth. A large three-jointed exopodite is present; in the first maxilla the large epipodite, produced from the coxopodite, stretches out over the slender endopodite which attaches a small exopodite to the proximal part. The basiopodite is certainly present under the epipodite; in the second maxilla a scaphognite is well developed and composed of three parts combined. There are very long hairs on the lower margin. Next to this large lobe are exopodite, palp and endopodite. The exopodite is simple, having something to protrude on the upper part of ventral surface, and it contacts with the scaphognite along its lateral part. The palp is composed of two separations, and under the palp the endopodite exists with those of a large and a small separations. The broad ischiopodite is fused together with the first endopodite on the ventral surface.

In the first pereiopod or first maxilliped an epipodite, which is likely to be fused with two laminae, is thin and transparent, produced from the coxopodite which lies along the ventral surface of basiopodite. The basiopodite is clearly divided into two separations as well as that of the antenna, the inner with a large three-jointed exopodite and a two-jointed palp, and the outer a large endopodite much like a leaf. Only one arthrobranch exists; in the second pereiopodite the epipodite is one with a large trichobranch which comes from the coxopodite. The exopodite, slender and large, is similar to that of the first pereiopodite. The endopodite consists of large four segments, joining with the two proximal segments; in the third pereiopod the inner surface of ischiopodite has an endopodite with a series of small four teeth at the proximal, to which nine teeth are continued. The outer surface is covered with thick hairs, or most often worsted hairs as we see them in the other specimens. The exopodite is much like that of the former two pereiopods in the first and second. There exist two epipodites with one podobranch which is larger than the second epipodite, that is very characteristic. On top of the first epipodite is a little concave with small nine setae, which are joining to distinct four setae at the inner side of lateral margin. The outer side of lateral margin is arranged with two series of setae, each of them being composed of nine.

In the fourth pereiopod or cheliped, the left and right are almost equal, $35.0 \mathrm{~mm}$ in length. The coxopodite, ischiopodite, basiopodite, meropodite and 
carpopodite are $2.9,2.0,4.8,9.2$ and $5.6 \mathrm{~mm}$ in length. In the propodus the left one is larger than the right, in the former the length of lower margin is $15.7 \mathrm{~mm}$, that of upper margin $5.9 \mathrm{~mm}$ and its height $8.5 \mathrm{~mm}$. On the contrary in the latter they are $14.7,7.0$ and $7.0 \mathrm{~mm}$. In the dactylopodite, the left one is $8.7 \mathrm{~mm}$ in length and $3.2 \mathrm{~mm}$ in depth, and the right 10.5 and $2.7 \mathrm{~mm}$. All the outer surface of the dactylopodite, carpopodite and partly the upper part of meropodite are coverd with villi thickly. The fifth, sixth, seventh and eighth pereiopods are $26.0,27.5,24.0$ and $23.0 \mathrm{~mm}$ in length, having a small rudiment of exopodite at the root of ischiopodite; in the fifth pereiopod the coxopodite, ischiopodite, meropodite, carpopodite and dactylopodite are 2.0, 0.9, 4.0, 8.5, 4.0, 6.0 and $4.5 \mathrm{~mm}$. In the meropodite and propodite they take a depressed form. On an outer surface of dactylopodite there is a series of short hairs along the middle line. At the proximal, both of coxopodites are closed together like that of the former pereiopod. There are two epipodites with one podobranch. Two arthrobranchs present; in the sixth pereiopodite, the coxopodite, ischiopodite, meropodite, carpopodite, propopodite and dactylopodite are 2.5, 2.4, 3.0, 9.0, 6.0, 5.0 and $2.9 \mathrm{~mm}$. Two epipodites and one podobranch present. There are some distance $(2.7 \mathrm{~mm})$ between coxopodites, and in them develops characteristically a thoracic sternite which is called a diamond-shaped thickening (Holthuis, 1958). In the seventh pereiopod they are $2.1,1.5,2.8,7.0,5.1,4.6$ and $2.5 \mathrm{~mm}$. One epipodite and one mastigobranch are present. Two arthrobranchs exist; in the last eight pereiopodite they are $2.5,1.0,2.7,6.2,4.5,4.8$ and $2.4 \mathrm{~mm}$, and its outline is much like that of the sixth and seventh. The thoracic sternite is well developed between coxopodites, and fused with that of the first abdominal segment. No epipodites and gills.

The first pleopodite is two-jointed in female, but wanting in male. The last segment of the first as likely as a broad filament with hairs, is longer than the basal segment; the pleopods on the second to fifth are biramous and larger than that of the first. There are many yellow eggs attached to all pleopods from the first to fifth.

In the sixth pleopod there is a suture on both exopodite and endopodite.

No appendix interna and masculina present.

Colour in life.-Materials are, as usual, coverd with reddish brown grain-like particles all over the surface and its hairs, but taking their coverings off from the surface, all the texture turns to white.

Habitat.- They are hollowers in the muddy sand of tidal zone, their openings of holes circling around with piled sand.

Distribution.--Tokyo Bay; Fukuoka; Amakusa; Kagoshima; Iriomote-jima, Ryukyu; Schuan, Korea. 


\section{Remarks}

I've just settled the structure of Laomedia astacina DE HAAN, which had been uncertain about gnathobranchs. In regard to gill number, the result obtained on the analysis of Laomedia seems to be the same as GuRnEY (1942) who had described for Jaxea and Naushonia. But there are some questions as to the gill formula. GURNEY regarded mastigobranchs and epipodites as the same ones, but, I think, mastigobranchs brimed with hairs must be differentiated from smooth and unhairy epipodites. In Laomedia mastigobranch is surely present only in the seventh

Table 1. Gill formula of Laomedia astacina.

\begin{tabular}{c|c|c|c|c|c|c|c|c}
\hline \hline P. & I & II & III & IV & V & VI & VII & VIII \\
\hline Pd. & (r) & 1 & 1 & 1 & 1 & 1 & - & - \\
A. & 1 & 2 & 2 & $2 \mathrm{e}$ & $2 \mathrm{e}$ & $2 \mathrm{e}$ & e.m & - \\
Pl. & - & - & - & - & 2 & 2 & 2 & - \\
\hline
\end{tabular}

e, epipodite ; A, arthrobranch ; $\mathrm{m}$, mastigobranch ; $\mathrm{P}$, pereiopodite ; $\mathrm{Pl}$, pleurobranch ; $r$, rudimentary.

pereiopodite. The first epipodites of the second to sixth pereiopodites are somewhat twisted, transparent, and correspondent to the mastigobranch of the seventh pereiopodite. In addition to them, the small second epipodites are present at the proximal part of epipodites of the third to seventh pereiopodites. Gills or correctly podobranchs are very poor in form, as they are likely to arthrobranchs, but podobranch of the second pereiopodite only takes a large triangular form. As a result, although this material has two epipodites in the third to seventh pereiopodites, there remain further questions whether foreign materials have such second epipodites as I've seen in Laomedia. I wish to suggest here about Laomedia having a most primitive gill number, as well as gill formula, because, as we know, there are 18 gills in Laomedia, while 12-16 gills in Axiidae, 15 gills in Thalassinidae and 10 gills in Callianassidae (ORTMANN, 1892).

Recently I've a deep interest to see egg formula, how eggs to adhere to pleopods. The first pleopod of Laomedia is small and two-jointed in female, and the second to fifth pleopods are biramous and larger than the first, and their eggs attach to all pleopods, as in Nephrops japonicus Tapparone Canefri, Nephrops sagamiensis PARISI and Nephropsis thomsoni (BATE). I've observed the same egg formula in Upogebiinae as in Laomedia, and it seems that individuals of Laomedia are systematically much nearer to Nephrops than others in Thalassinidea. As we see, the first pleopod of Thalassinidae and Axiidae is small and two-jointed without eggs, but the second to fifth are larger than the first with eggs. Two species of Callianassinae, C. petalula Stimpson and C. harmandi 
Bouviek have a peculiar type of egg formula. The first pleopod is small and two-jointed with eggs, the second small biramous and two-jointed with eggs, too, but third to fifth are broad and larger than the former ones without eggs. It will hint about hermit crabs, because their common species have eggs in the first to third pleopods, but not in the last or fourth one. I wish further to know whether this character of egg formula fits to all species of Thalassinidea.

As Dr. I. Gordon have pointed out to me during her visiting to our Laboratory in April 1961, thoracic sternite of the seventh pereiopod is a most important character. I think that there are two series of strains, the one, Axiidae and Upogebiinae, and the other, Thalassinidae, Laomediidae and Callianassinae. Thoracic sternite of Axiidae is concave much like that of penaeid prawns. On the contrary thoracic sternite of Thalassina anomala (HERBsT) fairly develops and suggests that of Nephropsis stwarti Wood-MASON. Thoracic sternite of Laomedia is a little convex and incised with distinct notch. In Callianassinae, C. petalura and $C$. harmandi, it is a little convex as we see in Thalassina and Laomedia.

There is another problem about cervical groove, which divides gastric and mascular regions in Laomedia, Thalassina, Axiidae and Upogebiinae, but not in Callianassinae. In Callianassinae it is deficient in what the former species mean. The cervical groove in Callianassinae divides mascular and cardiac regions.

Further studies into the systematic problems in Thalassinidae are necessary, but I think these characters of gill formula and its number, egg formula, thoracic sternite in the seventh pereiopodite and cervical groove, to be most important for the systematic.

\section{LITERATURE}

Borradarle, L. A., 1903. On the classification of the Thalassinidea. Ann. Mag. Nat. Hist., ser. 7, vol. 12 , pp. $540,549,550$.

Gurney, R,, 1942. Larvae of decapod Crustacea, London, p. 150.

DE HAAN, W., 1833-1850. VON SiebolD's 'Fauna Japonica', Crust., I. pp. 146, 162, 164 (1841), and 165 (1849), pl. 35, fig. 8.

Holthuis, L. B., 1958. An annotated list of the decapod of the Mediterranean coast of Israel. Bull. Res. council of Israel, sec. B, vol. 7B, no. 1-2, P. 60 .

KamitA, T., 1957. Studies on the decapod crustaceans of Corea, II. Scientific Reports of the Shimane Univ., no. 7, pp. 105-106.

Ortmann, A. E., 1892. Die Decapoden-Krebse des Strassburger Museums, III. Zool. Jahrb., Syst., vol. VI, pp. 49, 51-52. 


\section{EXPLANATION OF PLATES V-VII}

\section{Plate V}

Fig. 1. Female (Cat. No. $\mathrm{s}-54)$ in berry, lateral aspect. ( $\times$ ca. 1.5)

Fig. 2. The same, dorsal aspect. ( $\times$ ca. 1.5)

Fig. 3. Carapace, lateral aspect, showing mostly gastric, mascular, cardiac, posterior, anterior, maxillary, branchial regions and marginal zone. ( $\times$ ca. 2.5 )

Fig. 4. Anterior part of carapace and basal parts of antennae, dorsal aspect. ( $\times$ ca. 5.5 )

Fig. 5. Inner lateral phase of antenna, showing that upper and lower sections of lateral side in ischiopodite are the root of main part of ischiopodite. ( $x$ ca. 10)

Fig. 6. Upper phase of antenna, showing that exopodite or antennal thorn and palp or antennal scale are produced from separated two basiopodites. ( $x$ ca. 10$)$

\section{Plate VI}

Fig. 7. Mandible, dorsal aspect, showing that endopodite ends in six teeth and exopodite consists of three joints. $(\times 3)$

Fig. 8. First maxilla, dorsal aspect, showing that epipodite spreads out over both basiopodite and coxopodite, and from the basiopodite come endopodite and exopodite. $(\times 3)$

Fig. 9. Second maxilla, outer aspect. $(\times 3)$

Fig. 10. Second maxilla, inner aspect, showing exopodite, palp and endopodite come from basiopodite. Epipodite joins with coxopodite. ( $\times$ ca. 3.5)

Fig. 11. First pereiopodite or maxilliped, outer aspect. $(\times 3)$

Fig. 12. First pereiopodite, inner aspect, showing that epipodite joins with coxopodite of backing separated two basiopodites. Palp and exopodite come from outer basiopodite, but endopodite from inner one. ( $\times$ ca. 3.5$)$

Fig. 13. Second pereiopodite or maxilliped, with first epipodite and large triangular podobranch, outer aspect. $(\times 3)$

Fig. 14. Third pereiopodite or maxilliped, outer aspect. $(\times 3)$

Fig. 15. Epipodite of third pereiopod, outer aspect, showing first and second epipodites with podobranch. $(\times 3)$

Fig. 16. Top of second epipodite of third pereiopodite. ( $\times$ ca. 6$)$ 


\section{Plate VII}

Fig. 17. Left side of fourth pereiopodite or cheliped, outer aspect. $(\times 3)$

Fig. 18. Right side of fourth pereiopodite or cheliped, outer aspect. $(\times 3)$

Fig. 19. Fifth pereiopodite, outer aspect. $(\times 3)$

Fig. 20. Epipodite of fifth pereiopodite, inner aspect, showing first and second epipodites with podobranch. $(\times 3)$

Fig. 21. Sixth pereiopodite, outer aspect. $(\times 3)$

Fig. 22. Epipodite of sixth pereiopodite, outer aspect, showing first and second epipodites with podobranch. $(\times 3)$

Fig. 23. Epipodite of seventh pereiopodite, outer aspect, showing mastigobranch and second epipodite. $(\times \mathbf{3})$

Fig. 24. Telson and uropod, dorsal aspect. $(\times 3)$

Fig. 25. Thoracic part, ventral aspect, showing that left and right coxopodites in fourth, fifth and sixth pereiopods approach each other, but those in seventh and eighth don't approach, though their thoracic sternites are fairly well developed. $(\times 3)$

\section{List of abbreviations used in the figures}

\author{
a. antennal region. \\ B. basiopodite. \\ b. branchial region. \\ c. cardiac region. \\ co. coxopodite. \\ en. endopodite. \\ ep. epipodite. \\ 1 ep. the first epipodite. \\ 2 ep. the second epipodite. \\ ex. exopodite. \\ g. gastric region. \\ I. ischiopodite. \\ I. 1. lower section of lateral side in \\ ischiopodite. \\ I. m. main part of ischiopodite. \\ I. u. upper section of lateral side in \\ ischiopodite. \\ M. meropodite. \\ ma. mascular region.
}
mb. mastigobranch.
$\mathrm{mx}$. maxillary region.
mz. marginal zone.
P. palp.
p. posterior region.
pb. podobranch.
S. 3 thoracic sternite in the third pereiopodite.
S. 7 thoracic sternite in the seventh pereiopodite.
S. 8 thoracic sternite in the eighth pereiopodite.
S. 1p abdominal sternite in the first abdominal segment.
IV. the fourth pereiopodite.
V. the fifth pereiopodite.
VI. the sixth pereiopodite.
VII. the eighth pereiopodite. 
Publ. Seto Mar. Biol. Lab., X, 1 (1962) PLATE V
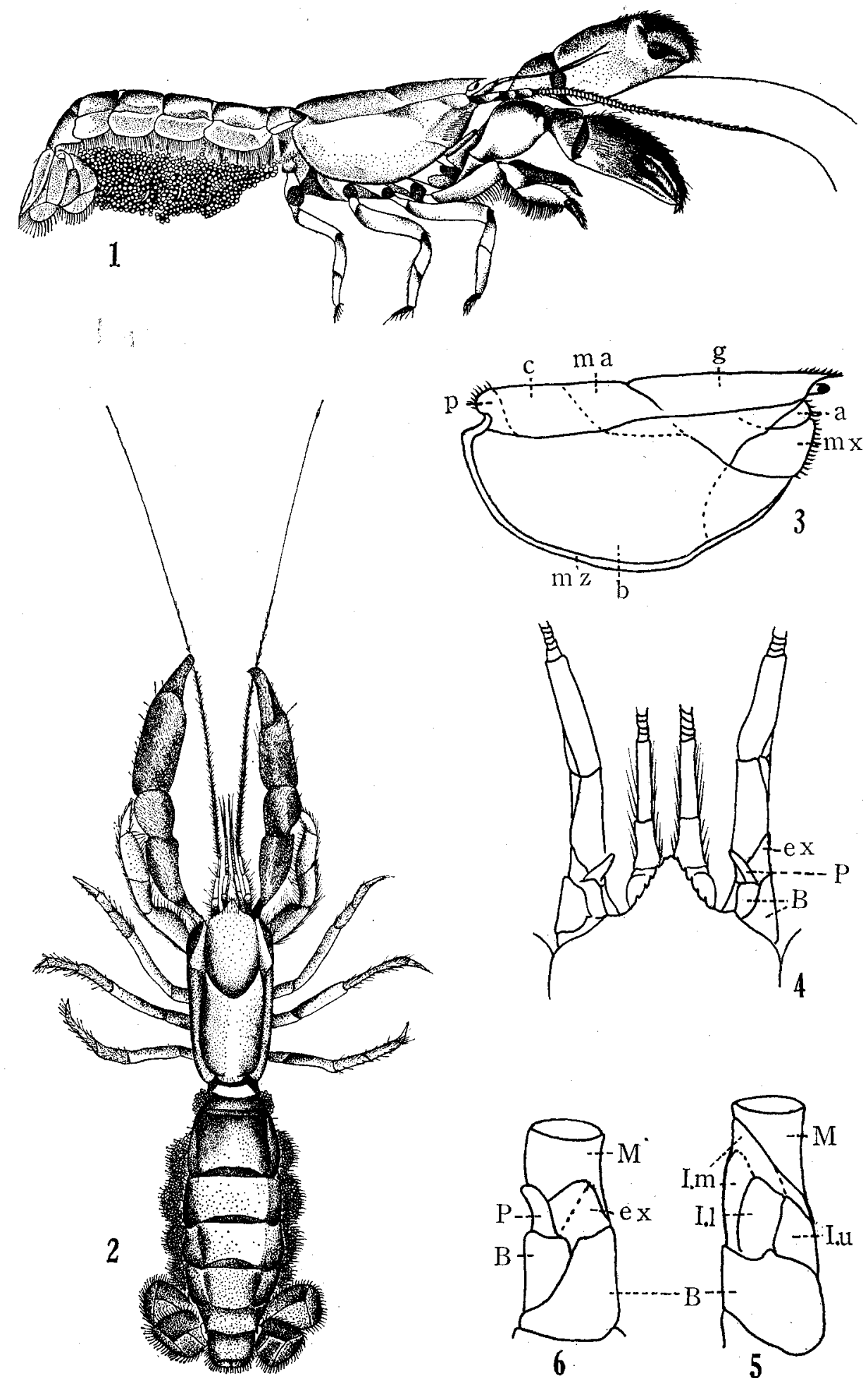

K. Sakai: Systematic Studies on Thalassinidea, I. 
Publ. Seto Mar. Biol. Lab., X, 1 (1962)
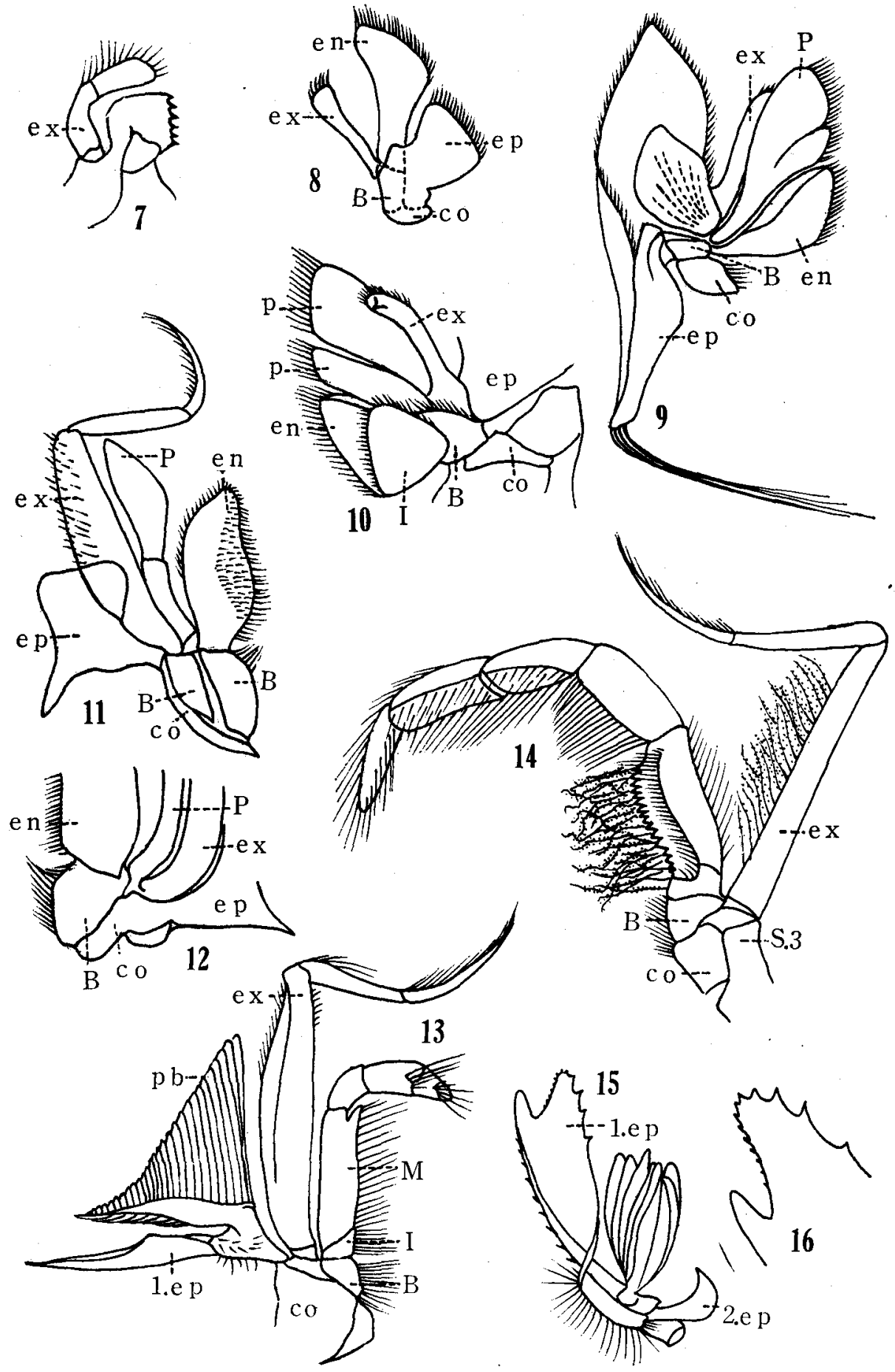

K. Sakai: Systematic Studies on Thalassinidea, I. 
Publ. Seto Mar. Biol. Lab., X, 1 (1962)
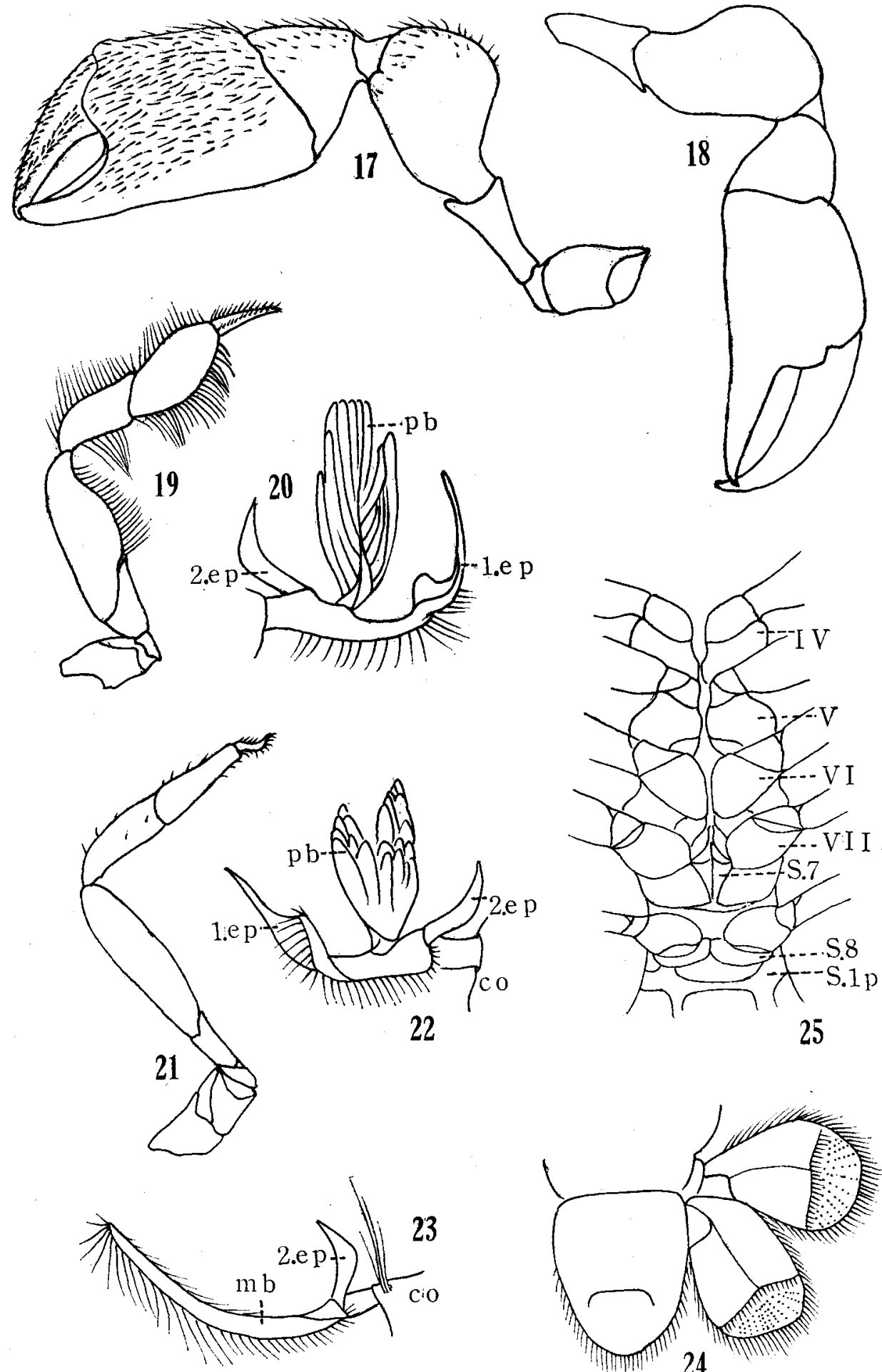

K. Sakai : Systematic Studies on Thalassinidea, I. 